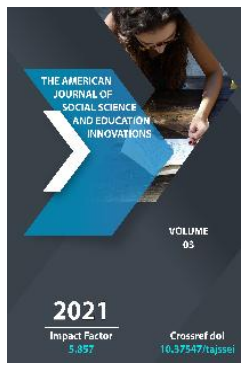

\title{
Pedagogical And Psychological Aspects Of Independent Education
}

\author{
Siddik Kakhkharovich Kakhkharov \\ Professor Of Bukhara State University, Uzbekistan \\ Shukhratjon Farmonovich Turaev \\ PhD Student Of Bukhara State University, Uzbekistan
}

\begin{abstract}
Journal Website:
http://theamericanjour

nals.com/index.php/taj

ssei

Copyright: Original content from this work may be used under the terms of the creative commons attributes 4.0 licence.
\end{abstract}

\section{ABSTRACT}

This article examines the question of self-learning from a pedagogical and psychological point of view. The principles of self-education are explained by age categories.

\section{KEYWORDS}

Knowledge, education, pedagogical technologies, independent learning, teaching materials, effective teaching, distance learning, students, motives for learning.

\section{INTRODUCTION}

There is no doubt that any changes in education can have a positive impact on society. One of the important factors in the training of competitive personnel that meets state educational standards is to increase the intellectual potential of the country. The organization of independent work of students under the guidance of a teacher is one of the 
most effective areas in the educational process, developing the ability to receive and consolidate knowledge. The desire to acquire knowledge independently is a distinctive feature of an educational institution, it is the basis for independent learning and acquiring knowledge. Self-directed learning and supervision in the education system are key factors in self-directed education. In order to acquire knowledge independently, it is necessary, first of all, to form students' need to work independently, freely, creatively and, most importantly, to have independent thinking.

Most self-directed learning is developed and supervised by the student and not by a third party such as an institution or teacher. Adults often use this approach to education, although children can also use it. The degree of success can depend on the level of motivation as well as the tools provided to the student. People who take the initiative still need support to achieve their goals and can use various resources through a library or similar means in a self-study project.

This process begins by defining the learning goal. Someone might want to learn how to knit, for example. After setting a goal, a slender person can develop a curriculum to achieve that goal, using a variety of tools and options to create clear personal direction. This can include the use of videos, texts, and tutoring to acquire a skill or learn more about a subject. Students set their own schedules and determine the level of depth involved in their learning experience.

Those interested in self-study can find a number of helpful resources. Some examples might include textbooks, curriculum from courses, and organizations that focus on specific topics of interest. Students looking for additional structure can request materials for courses that will take place at their own pace online or by mail. They use teaching materials to teach, but still guide themselves throughout the learning process and remain primarily accountable to themselves in the learning process.

Motivation appears when a person needs certain information or skills, which can only be obtained by changing the existing system of knowledge. Of course, in any society there are different levels of motivation.

Considering the issue of motivation to learn, professor of educational psychology John Monroe states: "We learn when we want to achieve a result that simply cannot be achieved with the knowledge that we have."

\section{MATERIALS AND METHODS}

\section{Motives for learning}

Monroe names the following types of learning motives with corresponding results: 


\begin{tabular}{|c|c|c|}
\hline $\begin{array}{l}\text { MOTIVES } \\
\text { FOR LEARNING }\end{array}$ & $\begin{array}{l}\text { TYPICAL ACTIONS TO BE TAKEN } \\
\text { FOR TRAINING }\end{array}$ & LEARNING OUTCOMES \\
\hline $\begin{array}{l}\text { A } \\
\text { SUPERFICIAL APPROACH }\end{array}$ & $\begin{array}{l}\text { Meet the minimum criteria and } \\
\text { requirements: pass the exam, } \\
\text { solve the problem }\end{array}$ & $\begin{array}{l}\text { Actions that allow you to } \\
\text { recreate the learned } \\
\text { information: memorizing, } \\
\text { memorizing, making notes }\end{array}$ \\
\hline IN-DEPTH APPROACH & $\begin{array}{l}\text { Understand ideas, know more, } \\
\text { solve problems, satisfy curiosity, } \\
\text { get satisfaction from achieving } \\
\text { long-term goals }\end{array}$ & $\begin{array}{l}\text { Actions that help to } \\
\text { understand: a detailed analysis } \\
\text { of ideas, the widest possible } \\
\text { study of them, correlation of } \\
\text { new ideas and already known } \\
\text { concepts }\end{array}$ \\
\hline STRATEGIC APPROACH & $\begin{array}{l}\text { Live up to expectations, reduce } \\
\text { stress from others, and feel } \\
\text { valuable Achieve excellence / } \\
\text { good grades / level / skills in the } \\
\text { game, get through the system, } \\
\text { secure your future }\end{array}$ & $\begin{array}{l}\text { Actions that allow you to } \\
\text { reproduce information in an } \\
\text { organized form: memorizing, } \\
\text { copying, correlating new ideas } \\
\text { with existing ones }\end{array}$ \\
\hline
\end{tabular}

In-depth and strategic learning approaches are built around the social and collective needs of learners when motivated by the desire to benefit and succeed in a social context. The concepts of "collective" and "social" do not refer to the learning process, but to the reason: why a person learns.

Monroe suggests that a person takes a deep and strategic approach to learning when he wants to solve problems or meet the expectations of others. For example, in the healthcare industry, nurses solve clinical problems to better care for patients or meet the expectations of their superiors.
Motives for learning strongly depend on the context: in different situations, at different stages of learning, different types and methods of learning will be relevant for different people.

For "superficial" students, it is enough to meet the minimum requirements, for example, to unlearn the required number of hours or to master a skill, so as not to lose their jobs. But students with a deep approach seek to solve problems and with curiosity seek answers to the questions they have. "Strategic" learners are motivated by progress, self-confidence and an inner need to always know more. 
The two main barriers to effective student learning are engagement and motivation. These barriers are manifested not only in the learning process, but also at the stage of applying the acquired knowledge. If you know the principles of adult learning, you can create quality e-courses. In this article, we will discuss these principles.

\section{RESULTS AND DISCUSSIONS}

How to put student learning principles into practice

The next time you teach a colleague, peer, or adult family member something new, remember the theoretical principles of adult learning: how and why they learn. You need to determine what your learner's approach to learning is - what drives him or her to learn or learn something new. Practical experiments show that for the result, observe the following rules:

- Create pre- and post-test tests so that students can critically assess their level of knowledge before and after training;

- Give the student the opportunity to independently manage the course of learning. For example, the choice: "Do you want to know more about methods of intravenous infusion or about catheters?";

- It is important for adult learners to know how new knowledge will affect them, why they are relevant and why they are needed, so focus on the problem that is being solved by learning. Do not overload students with unnecessary and unnecessary information.
- Find out what motivates a person to learn. Uses this to whet his interest. Example: "If you learn these rules, it will be easier for you to pass the exam because they will be on the test".

- Wherever possible, give case studies and practical examples from real life;

- Clearly define learning outcomes. Example: "At the end of the course, you will learn how to dress wounds using the aseptic method;

- You should also respect the student's work and the past experiences that he brings to learning.

\section{Learning Principles}

Andragogy is a theory that describes the characteristics of adult learning. Although the term itself dates back to the 1830s, today it is more often associated with Malcolm Knowles, who devoted a lot of scientific work to the characteristics of adult learners and how to improve their learning through science.

Knowles identified six key principles for adult learning:

1. The student's need for knowledge.

2. Self-awareness of the student .

3. Past student experience.

4. Willingness to learn. 
5. Attitude towards learning.

6. Motivation to learn.

\section{CONCLUSION}

All of these principles revolve around the same central ideas: motivation, self-directed learning, life experiences, goal-oriented learning, practical application, and respect.

\section{REFERENCES}

1. М. Лабкоский. Хочу и буду: Принять себя, полюбить жизнь и стать счастливым, Москва, 2018 год.

2. Стивена Кови, Семь навыков высокоэффективных людей. Лондон.

3. Safoyeva Sadokat Nasilloyevna. SYNONYMY AND ITS FEATURES, 4th Global Congress on Contemporary Sciences \& Advancements 3oth April, 2021 Hosted online from Rome, Italy econferecegloble.com. P. 120-121, https://papers.econferenceglobe.com/ index.php/ecg/article/view/400/397.

4. Kayumova Nigora Muxtorovna, Shukurova Nigora Shavkatovna, Safoeva Sadokat Nasilloevna. The Role of the Ethnographic Vocabulary in the English and Uzbek Languages, International Journal of Innovative Technology and Exploring Engineering (IJITEE) ISSN; 2278-3075, Volume-8, Issue-9S3, July 2019, P. 1551-1554.

5. Набиева Зарина Набиевна, АСТРИД ЛИНДГРЕН АСАРЛАРИДА КИЧКИНТОЙЛАР РУХИЯТИНИНГ БАДИИЙ ИФОДАСИДА ОБРАЗЛИЛИК. INNOVATION IN THE MODERN EDUCATION SYSTEM: a collection scientific works of the International scientific conference (25th May, 2021) - Washington, USA: "CESS", 2021. Part 6 - p.

6. Набиева Зарина, КИЧкИНТОЙЛАР РУХИЯТИНИНГ

БАДИИЙ ИФОДАСИДА ОБРАЗЛИЛИК. ПЕДАГОГИКА ВА ПСИХОЛОГИЯДА ИННОВАЦИЯЛАР ИННОВАЦИИ В ПЕДАГОГИКЕ И ПСИХОЛОГИИ INNOVATIONS IN PEDAGOGY AND PSYCHOLOGY №3 (2021) DOI http://dx.doi.org/10.26739/2181-95132021-3, Б. 62-67.

7. NabiyevaZ.N. The similarities and differences of proverbs with other genres International journal of Psychosocial Rehabilitation, vol.24, Issue 06,2020 ISSN;1475-7192 mart

8. Nabiyeva Zarina Nabiyevna "Image In The Artistic Expression Of The Spirit of Children" INTERNATIONAL JOURNAL ON ORANGE TECHNOLOGIES www.journalsresearchparks.org/index .php/IJOT e- ISSN: 2615-8140|p-ISSN: 2615-7071 Volume: 03 Issue: 03 | March 2021

9. NabiyevaZarinaNabiyevna** "STUDY OF FRENCH GASTRONOMIC CULTURE AND THE PROBLEMOF RECIPE TEXT"ACADEMICIA: An International Multidisciplinary Research Journal https://saarj.com

ISSN: 2249-7137 Vol. 10, Issue 11, November 2020 Impact Factor: SJIF $2020=7.13$. DOI: $10.5958 / 2249-$ 7137.2020.01631.6

10. Атоева М.Ф. Периодичность обучения физике. Аспирант и соискатель. Москва, 2010. - №6. - С. 41-43.

11. M.F. Atoyeva. Interdisciplinary relations in physics course at specialized secondary education. The 
Way of Science. - Volgograd, 2016. №9 (31). - P.22-24.

12. M.F. Atoyeva. The significance of periodicity at teaching physics. The Way of Science. - Volgograd, 2016. № 10 (32). - P.62-64.

13. Атоева М.Ф. Эффективность обучения электродинамике на основе технологии периодичности. The Way of Science. - Volgograd, 2016. - № 10 (32). - P.65-66.

14. M.F. Atoyeva. Use of Periodicity in Teaching Physics. Eastern European Scientific Journal. - DüsseldorfGermany, 2017. № 4. -P. 35-39.

15. M.F. Atoyeva. Didactic foundations of inter-media relations in the training of university students. International Scientific Journal. Theoretical \& Applied Science. p-ISSN: 2308-4944 (print) e-ISSN: 2409-0085 (online). Year: 2020 Issue: 06 Volume: 86, P. 124.

16. M.F. Atoyeva, R. Safarova. Pedagogical integration as a means of forming professionally important qualities among students of a medical university. Academicia. ISSN: 2249-7137 Vol. 10, Issue 8, August 2020. Impact Factor: SJIF $2020=7.13$ ACADEMICIA: An International Multidisciplinary Research Journal https://saarj.comэ.

17. M.F. Atoyeva. Pedagogical Tests As An Element Of Types Of Pedagogical Technologies. The American Journal of Applied Sciences, 2(09), (TAJAS) SJIF5.276 DOI-10.37547/tajas Volume 2 Issue 9, 19.09.2020. ISSN 2689-09. 92 The USA Journals, USA www.usajournalshub.com/index.php/t ajas 164-169. Имп.5.2.
18. Farkhodovna, A. M. (2020). The problems of preparing students for the use of school physical experiment in the context of specialized education at secondary schools. European Journal of Research and Reflection in Educational Sciences, 8 (9), 164-167.

19. Saidov S.O., Fayzieva Kh. A., Yuldosheva N. B. Atoyeva M.F. The Elements of Organization of The Educational Process On The Basis of New Pedagogical Technologies. The American Journal of Applied Sciences, 2(09), (TAJAS) SJIF-5.276 DOI10.37547/tajas Volume 2 Issue 9, 19.09.2020. ISSN 2689-09.92 The USA Journals, USA www.usajournalshub.com/index.php/t ajas 164-169. Имп.5.2.

20. Atoeva Mehriniso Farhodovna, Arabov Jasur Olimboevich, Kobilov

Bakhtiyor Badriddinovich. (2020). Innovative Pedogogical Technologies For Training The Course Of Physics. The American Journal of Interdisciplinary Innovations and Research, 2(12), 82-91.

21. Kakhkharov S.K., Juraev H.O. Alternative energy sources. Textbook. - Tashkent: NisoPoligraph, 2016. - 214 p.

22. Juraev H.O. Training Materials for Alternative Energy Sources in Education//Eastern European Scientific Journal. -Düsseldorf, 2017. № 1. -p. 127-131.

23. JuraevKh.O. Ways of Using Educational Materials on Alternative Energy Sources at Physics Lessons//Eastern European Scientific 
Journal. -Düsseldorf, 2017. № 2. - P. 83-86.

24. Kakhkharov S.K., Juraev H.O. Use of alternative energy sources at natural sciences lessons// The Way of Science. - Volgograd, 2017. № 2. - P. 148-150.

25. Kahharov S.K., Juraev Kh.O., Khamdamova N.M. Использование учебных материалов по источникам альтернативной энергии в интеграции на уроках физике // Инновации в науке. - Novosibirsk, 2019. №5 5 (93). -P. 17-25.

26. JuraevKh. Ways of using educational materials on alternative energy sources at natural lessons// European science review. - Austria, 2018. № 1-2. -P. 177-180.

27. Juraev Kh. Training materials on sources of the alternative energy in integration of natural sciences // Humanities and Social Sciences in Europe: Achievements and Perspectives. - Vienna, 2015. - P. 3235.

28. Qahhorov S.Q., Samiev K.A., Jo'raev H.O. Process modeling in solar devices.Monograph. - Tashkent. ITAPRESS, 2014. - 208 p.

29. Juraev Kh.O., Khamdamova N.M. Using alternative energy sources in education // Modern humanitarian research. - Moscow, 2015. №3. - P. 42-48.

30. Каххоров С.К., Жураев Х.О., Жамилов Ю.Ю. Рециркуляционная солнечная сушильная установка // Наука и мир. - Волгоград, 2016. № 11 (39). - C. 26-28. http: // ziyo.edu.uz

http://uzref.uz

http://google.uz

http://google.uz

.

